\title{
DESIGNING A QUALITATIVE MODEL OF DOPING PHENOMENON EFFECT ON SPORT MARKETING IN IRAN
}

\author{
Jasem Manouchehri ${ }^{1}$ \\ Mehrzad Hamidi ${ }^{2}$ \\ S. Nasrolah Sajadi ${ }^{3}$ \\ Habib Honari ${ }^{4}$
}

\begin{abstract}
There are a number of factors affecting consumers' purchase behavior. It is believed that celebrities can affect companies' sale positively or negatively by transferring their image to the endorsed brand product. Regardless of positive effects, scandal, transgression, and any kind of misbehaviors may destroy sponsor companies' economics. The present paper mainly aimed to explore the effect of doping phenomenon on sport marketing. Qualitative data collecting from eighteen in-depth interviews with undergraduate students of the college of physical education and sport sciences of Islamic Azad University-Central Tehran Branch (IAUCTB) were analyzed in three phases: open coding, axial coding, and selective coding. 297 open codes were achieved by 18 interviews. Grouping and comparing axial codes in each case, all identified codes were divided in five groups: brand image (athlete and endorsed product brands images), moral reasoning (moral coupling, moral decoupling, and moral rationalization), consumer behavioral consequences (word of mouth, purchase intention, and brand loyalty), attitude change (attitudes change toward athlete and brand), and moral emotions (moral evaluation, contempt, anger, disgust, and sympathy). The proposed qualitative model for the effect of doping phenomenon on sport marketing in Iran illustrated that moral emotions and product brand image affected by the doped athlete brand image and it resulted in attitudes change toward endorser athlete and endorsed brand and negative consumer behavioral consequences, however, moral reasoning strategies emerged by cognitive dissonance might protect consumers behavior from negative effects.
\end{abstract}

Key Words: Qualitative Model, Doping, Marketing, Sport, Iran

${ }^{1} \mathrm{PhD}$ Candidate in Sport Management, Kish International Campus, University of Tehran, (Iran). Corresponding Author: j.manouchehri@iauctb.ac.ir

${ }^{2}$ Associate Professor in Sport Management, University of Tehran, (Iran).

E-mail: meh_hamidi@yahoo.com

${ }^{3}$ Professor in Sport Management, University of Tehran, (Iran). E-mail: nsajjadi@ut.ac.ir

${ }^{4}$ Associate Professor in Sport Management, Allameh Tabataba'i University, (Iran).

E-mail: honari@atu.ac.ir 


\section{INTRODUCTION}

Performance enhancing drugs usage has been seen through the history. It is believe that the root of "dope" was from South Africa and referred to drinking alcohol in religious celebrations although it was seen firstly in a English dictionary in 1879 (ASDA, 2000; Hoberman, 1992). Doping has had widespread usage and it has become a dilemma in sport since last decades.

On the other hand, sport marketing is one of the most substantial subjects in sport industry. Urban managers and entrepreneurs understood the political and financial benefits of hosting Olympics since early years of the modern Olympic movement. It leaded sponsors to adapt to the Olympic philosophy for achieving more portions in related products marketplace (Slack, 2004). The concept of marketing is used in various manners. Some defined it as using advertisement, personal and public sale methods to inform others about a product or to attract a costumer to purchase it. However, marketing definition is more comprehensive than these limited commentaries. Marketing is simply defined as "focusing on satisfying costumers' and consumers' needs". Sport consumers and costumers mostly involve in sport activities, watching or listening to sport programs, purchasing merchandises, collecting souvenirs, buying sport equipments such as shoes and clothes, or even following the last updated information of their interesting athletes, teams or events through a website (Smith, 2008).

There a number of factors affecting consumers' purchase behavior. Sport and event consumer behavior is defined as the process of selecting, buying, using, and leaving a sport product or service in order to satisfy needs and gain benefits (Funk,
2011). For instance, socio-cultural and collective factors, psychological and personal factors, situational factors and factors relating to marketing mix affect purchase decision making process (Roosta, Venous, \& Ebrahimi, 2013). The named factors may increase or decrease (negative effects) purchase behavior. Finding a definition which includes all criteria relating to a specific case is not feasible when we are defining the negative effects Although the concept of "negative marketing" is consider as a controversial marketing technique to create failure in an opponent corporation in order to overtake a competition.

Moreover, celebrities can affect companies' sale positively by transferring their popular image to the endorsed product (McCracken, 1986). Simmers, DamronMartinez, \& Haytko (2009) suggested that celebrity endorsers provide a tool for consumers to affect the transition concept. Utilizing a celebrity endorser, marketers will be able to illustrate the human features of their products through transferring celebrity's personal brand image (Aaker, 1997). On the other side, nowadays, excommunicate behaviors are heard frequently in the world of sport. As a consequence, sport and sponsorship can be affected in negative ways. Sponsors always are concerned of experiencing doping negative consequences relating to their products and brands since consumers' opinions on the sponsored products may be changed by these probable consequences (Florez, 2013).

In summary, the present paper expressed about scandal in sport and how it changes consumer behavior. As mentioned, celebrity endorser athletes affect a brand in a positive or negative way. Fans of famous 


\section{Designing a Qualitative Model of Doping Phenomenon Effect on Sport Marketing in}

Iran

athletes try to imitate their popular athletes' behaviors and life style and it can be considered as not only an opportunity but also a threat for companies' and corporations' sale promotion. The present research aimed to concept the study subject deeply since lack of sufficient related findings in Iran because it may has not been in interest of most Iranian scholars.

The authors commenced with reviewing literatures and documents to get know more about the study subject and designed a research methodology. Most of previous studies were about sport fans and their opinion on doping scandal. Few of them, as discussed in the literature part, focused on brand or consumer behavior and how they were affected by a scandal such as marital, raping, and doping transgressions. Reviewed literatures showed that both destructed brand and consumer behavior are considered as consequences of endorser's doping scandal and the main purpose of the researchers was to explore it by interviewees' related opinions.

The present study used a qualitative methodology because quantitative approach has limitation for in-depth conception. Therefore, an exploratory and qualitative approach was applied to scrutiny the doping phenomenon and its effect on sport marketing. Undergraduate students of college of physical education and sport sciences of Islamic Azad UniversityCentral Tehran Branch (IAUCTB) were considered as a targeted society in order to select interviewees. Eighteen interviews accomplished by attaining to theoretical saturation although repetitive data and codes appeared by the twelfth interview. Data analysis process had three phases including open coding (extracting data from the interviews texts, coding, and exploring themes), axial coding (creating groups and categories), and selective coding (reviewing and linking codes).

The importance of marketing activities in all industries and effectiveness of using celebrities for endorsing products leaded researcher to study the negative marketing specifically the negative impacts of convicted athletes on a company economics.

\section{Literature Review}

Disclosure of recent doping scandal affairs of Lance Armstrong's seven wins in Tour De France is just one among many spectacular cases. Public section of a TV channel showed condemnation of Patrik Sinkewitz, German cyclist, because of doping in Tour De France in 2007. Although this TV channel covered Tour de France again from 2008 to 2011, it withdrew covering the event in 2012 due to the sharp decrease in its number of spectators (Buechel, Emrich, \& Pohlkamp, 2014). It was reacted to the consequences by not only TV channels but also sponsors. For instance, Phonak, sponsor of a cycling team, withdrew supporting after the team leader (Floyd Landis) was convicted of doping. Therefore, the cycling history shows that stakeholders and sponsors reacted to doping disclosure by withdrawing their supports. However, it is undeniable that event organizers suffered significant harms due to relinquishing support by costumers, sponsors, and media corporations (Buechel, Emrich, \& Pohlkamp, 2014).

As already mentioned, this managerial dilemma in marketing context was emerged due to lack of understanding consumers' multi-dimensional responses to athletes' transgression. A research revealed that consumers respond differently to the same transgressions (Lohneiss \& Hill, 2014). Nevertheless, most previous studies on celebrity endorsers' transgressions have mainly focused on the role of transgression itself and its negative impact on endorsed brands from the associative memory network approach (for instance, Thwaites, Lowe, Monkhouse, \& Barnes, 2012; Till \& Shimp, 1998). Much of the attention in the literature has been paid to the outcome of a 


\section{Designing a Qualitative Model of Doping Phenomenon Effect on Sport Marketing in}

Iran

match-up between a troubled athlete and a brand. For instance, Till \& Shimp (1998) found that negative publicity regarding an athlete's transgression may influence consumer evaluations of an endorsed brand negatively. It means that the previous research sought to determine the consequences of transgressions on individual perceptions of endorsed brands. This approach neglects the fundamental question of 'how' consumers process the transgression information and arrive at their moral decisions. This 'how' question deserves research attention because it can provide answers about that diverse reasoning processes of sport consumers that lead to multifaceted responses towards the transgressors. Therefore, our knowledge of moral reasoning process of consumers can be expanded through: (a) a deeper understanding of 'how' preexisting perceptions of a celebrity endorser influence the moral judgment processes of consumers; and (b) how other internal/external factors impact moral judgment processes (Lee, 2015).

With respect to consumer moral reasoning processes, it is well documented that cognitive dissonance occurs when the consumers simultaneously hold an inconsistent set of cognitions: positive perceptions toward an athlete and negative perceptions toward a moral transgression committed by the athlete (Festinger, 1957). In order to cope with the disequilibrium, consumers become motivated to activate different moral reasoning routes. For instance, the literature has demonstrated that individuals often tend to activate moral disengagement strategies in order to either justify the unethical conduct (moral rationalization; Bandura, 1991), or to separate morality judgments from performance judgments (moral decoupling; Bhattacharjee, Berman, \& Reed, 2013). These moral disengagement processes help consumers become more forgiving and more willing to show their support for morally tainted athletes (Lee, 2015).

\section{Problem Statement}

Despite the evidence regarding rationalization and the separation of morality judgments, some consumers seem to find it difficult to do either, and thus conflate morality and performance judgments when they encounter celebrity athlete transgressions. For instance, some people still condemn Michael Vick, a professional football quarterback who pleaded guilty to promoting dog fighting saying "He's NOT a great football player," and "He is an animal...[with] little or no moral fiber. The NFL should not take him back!" (Perron, 2009). This evidence suggests that some people may find certain immoral actions to be morally impermissible, and may therefore be motivated to engage in strategies other than moral decoupling or rationalization. In some cases, it is plausible that consumers may integrate morality and performance judgments when they evaluate troubled athletes-this is referred to as moral coupling. Furthermore, the integration of performance and morality judgments can negatively impact a troubled athlete, and, in turn, the affiliated brands. More specifically, by integrating morality judgment with performance judgment, the image of troubled athletes may be contaminated, and the attenuated athlete images will in turn negatively affect associated brand evaluations (Lee, 2015). However, the existence of the moral coupling process, and its subsequent impact on troubled athletes and their respective endorsed brands, has not been investigated and documented in the literature to date.

Therefore, consumer behavior is considered a consequential concept because of its impact on companies' strategic decisions. By a negative impact on brand, company must analysis costumer's thoughts. In this way, effective marketing communication strategies can be implemented since costumer is the most marketing pillar (Florez, 2013). In any case, 
the present research was aimed to study literature and previous researches and provide preparations for implementing a qualitative study. Hence, qualitative interviews by participants were accomplished; meanwhile, items and factors affecting behavioral consequences

\section{Methodology}

\section{Research Design}

If a research aims to focus on hidden aspects of a phenomenon and its perception in humanities, social and behavioral fields, quantitative methodology cannot provide tangible results; in this case, qualitative methods are utilized (Bazargan, 2002). Qualitative data is based on qualitative data collection methods such as in-depth interview and observation in which textual data is provided and various perspectives on the studied subject are realized with a complex image of the phenomenon (Miles \& Huberman, 1994). On the other side, a research study has three specified criteria including result, aim, and data. The present research is a fundamental, exploratory, and qualitative study according to the criteria of results, aim, and data respectively.

A fictitious scenario was written about a famous athlete who had an endorsement contract with an energy drink company and he failed his doping test and become suspended from participating in any official competition for a period of four years. Moreover, all national, international and world medals and honors of him were taken back and he has been condemned to doping scandal. The idea of using a fictitious scenario rooted in a dissertation by Lee (2015).

All in-depth interviews were designed to ask about the mentioned scenario. Interviewees were free to discuss about the named scandal and they expressed their opinion about doping, doped athlete, of a sport consumer facing with a doped endorser athlete were explored and finally a qualitative model for the factors was presented. The main question of the research was "what is the effect of doping phenomenon on brand, consumer behavior, and generally sport marketing"?

endorsed product, and what would be happened to company and its marketing activities by the doping scandal. All discussions were recorded by a tape recorder after getting permission from interviewees. Facing with vague words of interviewees respecting to the queries, it was asked them to clarify their own opinion in detail to enable interviewer to analysis and apperceive collected data. Then, recorded voices were written and prepared for more analyzing by the methods of qualitative data analysis.

\section{Interviewees}

Undergraduate students of physical education and sport sciences were selected by a targeted approach. Based on qualitative methodology, in-depth interviews were implemented for collecting data till attaining to theoretical saturation. The fourteenth interview showed repetitive codes and it was eventually decided to stop data collection at the eighteenth interview. The present research was limited to the college of physical education and sport sciences of Islamic Azad UniversityCentral Tehran Branch (IAUCTB) in the period of 2015 to 2016. 


\section{Designing a Qualitative Model of Doping Phenomenon Effect on Sport Marketing in}

Iran

\section{Instruments and Data Analysis Approach}

General and open-ended questions relating to the case of doping phenomenon (the fictitious scenario) and its impact on sport marketing and more detailed questions emerged by responses and ideas of interviewees were asked for analyzing and realizing the discussion subject. Data analysis process had three phases including open coding (extracting data from the interviews texts, coding, and exploring themes), axial coding (creating groups and categories), and selective coding (reviewing and linking codes).

Open Coding: At this first level of coding, authors were looking for distinct concepts and categories in the data, which would form the basic units of their analysis. In other words, they were breaking down the data into first level concepts, or master headings, and second-level categories, or subheadings. Researchers often use highlights to distinguish concepts and categories (Research Rundowns, 2016).

Axial Coding: In open coding, researchers focused primarily on the text to define concepts and categories. In axial coding, concepts and categories are used while re-reading the text to 1 . Confirm that the concepts and categories accurately represent interview responses and, 2. Explore how the concepts and categories are related (Research Rundowns, 2016).

Selective Coding: At this first level of coding, final concepts and categories transferred into a data table (Table 1) and then the concepts were explained after the table. This is a very effective way to organize results and/or discussion in a research paper (Research Rundowns, 2016).

\section{Results}

\section{Demographic Results}

Results showed that, among all, interviewees active in ball sports, body building, martial arts, and swimming were $\% 28, \% 28, \% 39$, and $\% 5$ respectively. Among all, best interviewees' championships records in sport were different as provincial (\%50), regional (\%33.5), and national (\%16.5). Moreover, Results showed that interviewees' years of experience in sport were different as: less than 5 years (\%16.5), between 6 to 10 years (\%28), between 11 to 14 years (\%39), and above 15 years $(\% 16.5)$. likewise, \%33.5 were less than 25 years old, $\% 28$ were between 26 to 30 years old, \%22 were between 31 to 35 years old, and \%16.5 were above 36 years old. Men and women were totally 18 (9 men and 9 women) with the mean age of 28.83 .

\section{First Phase Results: Open Coding}

The first phase includes three steps of extracting data from the interviews texts, coding, and exploring themes. In the present research, all interviews contents were written down and open coding step was accomplished by coding key points. Key points coding method commenced with written down all collected data in interviews and after that open codes were created by analyzing text paragraph by paragraph and line by line.

For instance, some open codes extracted from a participant's interview were presented in Table 1 in which some codes are the actual words said by the interviewee. Analyzing eighteen interviews, it resulted in 297 open codes totally.

\section{Second Phase Results: Axial Coding}

In axial coding, created codes of the previous phase were rewritten with a new method in order to linking codes. Axial coding resulted in groups and categories creation. Same themes were placed in a specific group and all created codes were 


\section{Designing a Qualitative Model of Doping Phenomenon Effect on Sport Marketing in \\ Iran}

reviewed again and compared with texts to make sure that no key content was omitted. The present phase resulted in one axial code which may cover many open codes. All 297 open codes made 186 axial codes (Table 1).

Table 1. A Sample of Open and Axial Coding

\begin{tabular}{|c|c|c|c|}
\hline Marker & Interview text (key points) & Open coding & Axial coding \\
\hline P2 & $\begin{array}{c}\text { A very unfavorable image is in my mind. I do not like } \\
\text { him. I hate him. }\end{array}$ & $\begin{array}{c}\text { Very unfavorable } \\
\text { image of athlete }\end{array}$ & $\begin{array}{c}\text { unfavorable } \\
\text { athlete image }\end{array}$ \\
\hline P14 & I definitely do not buy the product. & Not buying endorsed \\
p20 & $\begin{array}{c}\text { I will say that it is not a good product since my mind } \\
\text { changed negatively and I won't recommend it. }\end{array}$ & $\begin{array}{c}\text { Transferring negative } \\
\text { words about product }\end{array}$ & Expressing \\
P23 & $\begin{array}{c}\text { My mind has become negative of the endorsed product } \\
\text { by the doped athlete. }\end{array}$ & $\begin{array}{c}\text { Negative product } \\
\text { brand image }\end{array}$ & $\begin{array}{c}\text { Negative effects } \\
\text { on brand }\end{array}$ \\
\hline P24 & $\begin{array}{c}\text { In my idea, doping has negative effects on brand. It } \\
\text { has negative effects on company advertisements, all } \\
\text { undertaken costs, and desired quality for presentation. } \\
\text { It has also negative impact on the company brand. }\end{array}$ & $\begin{array}{c}\text { Negative effects of } \\
\text { the doped athlete on } \\
\text { the company brand }\end{array}$ & \\
\hline
\end{tabular}

\section{Third Phase Results: Selective Coding}

Based on the previous phases, selective coding is the main phase for theorizing. In this phase, each category must be linked to other categories systematically and those links should be presented in narrative style and also categories needed improvement and development will be revised (Danaeifar, Alvani, \& Azar, 2013).

Categorizing extracted axial codes were completed by grouping codes and all groups were compared with each other in order to identify and extract main groups and dimensions. However, reviewing research literature assisted authors to grouping more accurately. The present research tried to illustrate findings of doping effect on marketing in narrative according to the paradigm model framework. Grouping and comparing axial codes showed that it is possible to divide all gained codes in five main groups (Table 2):
Brand Image: brand image codes included athlete brand image (ABI), endorsed product brand image (PBI), and company brand image (CBI).

Moral Reasoning Emerged by Cognitive Dissonance: moral reasoning codes included moral coupling (MC), moral decoupling (MD), and moral rationalization (MR).

Consumer Behavioral Consequences: consumer behavioral consequences codes included word of mouth (WoM), purchase intention (PI), and brand loyalty (BL).

Attitude Change: the codes of attitudes change toward athlete and endorsed brand included affective attitude change (AAC), cognitive attitude change (CAC), and behavioral attitude change (BAC).

Moral Emotions: moral emotions codes included moral evaluation (ME), contempt, anger, disgust (CAD), and sympathy (Sym.). 


\section{Designing a Qualitative Model of Doping Phenomenon Effect on Sport Marketing in}

Iran

Table 2. Dimensions of the Main Explored Groups

\begin{tabular}{|c|c|c|c|c|}
\hline $\begin{array}{l}\text { Brand } \\
\text { Image }\end{array}$ & Moral Reasoning & $\begin{array}{c}\text { Consumer Behavioral } \\
\text { Consequences }\end{array}$ & Attitude Change & Moral Emotions \\
\hline 1) $\mathrm{ABI}$ & 1) $\mathrm{MC}$ & 1) $\mathrm{WoM}$ & 1) $\mathrm{AAC}$ & 1) $\mathrm{ME}$ \\
\hline PBI & 2) $\mathrm{MD}$ & 2) $\mathrm{PI}$ & 2) $\mathrm{CAC}$ & 2) $\mathrm{CAD}$ \\
\hline CBI & MR & 3) $\mathrm{BL}$ & 3) $\mathrm{BAC}$ & 3) Sym. \\
\hline
\end{tabular}

Based on the grounded theory method, dimensions emerged by analyzing data are as following:

Athlete Brand Image (ABI): Dilger, Frick, \& Tolsdorf (2007) realized a fundamental assumption in most of literatures indicating event organizers and spectators prefer clean athletes. However, Prinz (2006) said differently indicating "Gladiator Effect" exists in sport competitions and it leads spectators to do not care of what kind of tools athlete utilized for winning and they just interested in and pay attention to the competitions. Generally, any kind of transgression of athletes can result in image change with fans. Data analysis showed all interviewees knew doping as an ominous and unacceptable phenomenon and doped athlete image as an undesirable one.

Product Brand Image (PBI): Brand image may have a close relationship with its identity and personality including personal features which are specifically different with other brand images (Aaker, 2008; p. 168). Product brand image can be empowered or destroyed by sport celebrities' endorsement. According to the interviewees, product brand image may promote by celebrity athlete's endorsement or destroyed by him/her doping transgression and, as a consequence, it leads consumer to hate of the product. In the case of doping transgression of an athlete endorser, athlete's negative advertisement results in destroying product image and transferring athlete's image to the related product.
Company Brand Image (CBI): Since the company brand image was general brand image of the Hype company in this research, transferring a doped athlete' image to product brand may affect the company image. According to the interviewees, company brand image can be destroyed after doping transgression of the endorser athlete. Most of participants believed that a destroyed image of product affects not only other products but also all company negatively. Some believed that destroyed brand image will be forgotten after a short period of time and then company would be able to move toward improvement and compensate past harms.

Moral Coupling (MC): Ominous doping phenomenon is unbearable and hateful for most of people. Drug usage is not only a threat for athletes' health, sport value and nature but also is the most ethical and health challenge in the view of most sport organizations (Houlihan, 2002). Therefore, all interviewees were disagree with the named phenomenon and most of them convicted doping and doped athlete and withdrew of using the product because of their believe on the relationship between athlete's unethical act, endorsement and the product as mentioned in the fictitious scenario. Consequently, moral coupling is considered as a strong relation between a doped athlete and his/her endorsement activities which have direct and destructive effect on consumer behavioral consequences.

$$
\text { Moral Decoupling (MD): }
$$

Bhattacharjee, Berman, \& Reed (2013) 


\section{Designing a Qualitative Model of Doping Phenomenon Effect on Sport Marketing in}

Iran

defined moral decoupling as "the process of mental separation in which consumers dissociate ethical judgments from performance judgments selectively" (Page 1168). In the case of endorsement of doped celebrity athlete's, interviewees who were disagree with doping but they liked their athlete clarified that there is no connection between endorsed product and athlete's doping and they should not be considered as related to each other. In fact, emerged cognitive dissonance in negative attitude of doping and their supportive purchase behavior resulted in a moral reasoning stating that there are not relations among the endorsed product and endorser's doping. In other words, it was expected that negative attitude toward doping might result in negative consumer behavioral consequences but moral decoupling seems that played as a moderator factor.

Moral Rationalization (MR):

Bhattacharjee, Berman, \& Reed (2013) defined moral rationalization as "the process of reconstructing unethical acts to less unethical in order to keep supporting unethical actor" (Page 1168). Other interviewees who were not opposed transgression of the named athlete in the scenario clarified that doping is not as important as other jeopardy and harmful violations of society. Therefore, it seems that being interested, committed and fan of the athlete will leads to rationalization of doping in sport and society and a violated athlete won't be considered as a great and significant offender. In the case of endorsement and negative publicity affecting consumer behavioral consequences, moral rationalization is a reasoning strategy and has a moderating role and it may reduce destructive effects of athlete violation on word of mouth, purchase intention, and brand loyalty.

Word of Mouth (WoM): Litvin, Goldsmith, \& Pan (2008) defined word of mouth os communications between consumers about product, services or company in which resources consider separated from commercial influence. Westbrook (1987) also defined it as all informal communications of people with others about ownership, usage, features, or goods and services seller. Data analysis revealed that product consumers venture to transfer negative words on product and its brand when they face with doping condemnation and a doped celebrity athlete to oppose related endorsed product. Interviewees believed that they would say about harms and negative points of the product and express negative and destructive words on the product when they face with product related discussions. However, some of them believed that they won't say negative words about product if they already satisfied with product quality.

Purchase Intention (PI): Blackwell, Miniard, \& Engel (2001) defined purchase intention as something that costumer thinks that must to buy. Purchase intention is one of the consumer behavioral consequences studied in this research. Results showed that all interviewees were against doping, doped athlete, and ethical violation and they won't re-purchase the endorsed product any more. Negative emotions emerged about the doped athlete and transferring them to the product will lead consumers to do not buy that again. Although, some people believed that company and athlete's ethical scandal will be forgotten after a short period of time and consumers will return to buy and use the product.

Brand Loyalty (BL): Loyalty is an important concept in marketing strategy and, according to the Aaker, brand loyalty in the core of brand equity and causes costumers to look less for information among solutions. Brand loyalty was another consumer behavioral consequence which was asked interviewees about athlete brand, product brand, and company brand. They believed that they will be no more fan of the athlete after doping scandal and they will cease supporting him. They also believed that they won't re-purchase the product and will lose loyalty toward the company. 


\section{Designing a Qualitative Model of Doping Phenomenon Effect on Sport Marketing in}

Iran

However, people who faced with cognitive dissonance and conflicting attitudes do not miss their loyalty toward the product. Additionally, others who already satisfied with the product quality did not consider it related to the athlete's doping scandal and they remained loyal to the product.

Affective Attitude Change (AAC): According to Wilkie (1986), brand attitude is consumer general evaluation of brand. Brand attitude is physical relation among a consumer and a brand including dimensions of mutual relations and consumer attitude toward brand (Fazen, 1999). Respecting to the research findings, words evaluating athlete, doping, and violation are negative which mean negative attitudes toward athlete and endorsed product. In the case of affective attitude, interviewees said negative words about the doped athlete, product and company brand after doping violation and it means changes happened to their affective attitude.

Cognitive Attitude Change (CAC): People tend to judge a celebrity convicted to an unethical decadence in two ways: holistically good or bad. Results showed that, in addition to affective attitude changes of consumer and negative evaluative words on athlete, product and company, it seemed that negative feelings emerged and discomfort and hatred were apparent in interviewees' words. Cognitive attitude is the second dimension of attitude in which person's feeling on a phenomenon is clarified.

Behavioral Attitude Change (BAC): As attitude refers to the words evaluating a phenomenon or a product and it leads to shape feelings, behavioral attitude is considered as the third dimension of attitude indicating potential and probable behavior for future. Base on the research findings and interviewees' opinions indicating no support and commitment to athlete, withdraw from purchasing product, and negative attitude toward company brand, behavioral attitude change was negatively happened to consumer and it might lead to potential destructive consequences to consumer behavior.

Moral Evaluation (ME): Perception of athlete transgression has negative effect on the endorsed brand evaluation through linking violated athlete to that. For instance, as already mentioned, people tend to judge a celebrity convicted to an unethical decadence holistically good or bad. Endorser athlete's violations are considered unethical not only to consumer who developed deep emotional attachments but also other consumers who are apathetic of them. In view of moral psychology theory, moral emotions happen directly and automatically and moral reasoning looks for creating moral reasons (Haidt, 2001). Respecting to the interviewees' ideas and analyzed data, any of athlete's transgressions, specially doping violation, lead to negative moral evaluation and athlete image destruction.

Contempt, Anger, Disgust (CAD): To be exposed to moral standards violation may lead to negative emotional reactions in consumers' mind simultaneously and spontaneously (Grappi, Romani, \& Bagozzi, 2013; Haidt, 2001). Emotional responses play a vital role in evaluating and reacting to a convicted person. Among various moral emotions, people experience other-critical emotions (for instance, Contempt, Anger, and Disgust; Rozin, Lowery, Imada, \& Haidt, 1999; page 575) when ethical and social transgressions violate moral standards (Haidt, 2001, 2007; Tangney, Stuewig, \& Mashek, 2007). In the case of negative moral emotions, data analysis showed that irritation of athlete's doping violation to fans is inevitable and results in hatred and unforgiveness feeling to consumer.

Sympathy (Sym.): As an affective emotion, interviewees felt sympathy for athlete after doping although transgression and unethical violation of doping was obvious to them. They believed that it 
would be possible to be fans of him if he compensates and does not commit again.

\section{Qualitative Model of Doping Phenomenon Effect on Sport Marketing}

The proposed research model was designed in accordance to the results of data analysis and literature. In the literature, it was clarified that above dimensions have significant roles in the following model based on other existing models in literature.

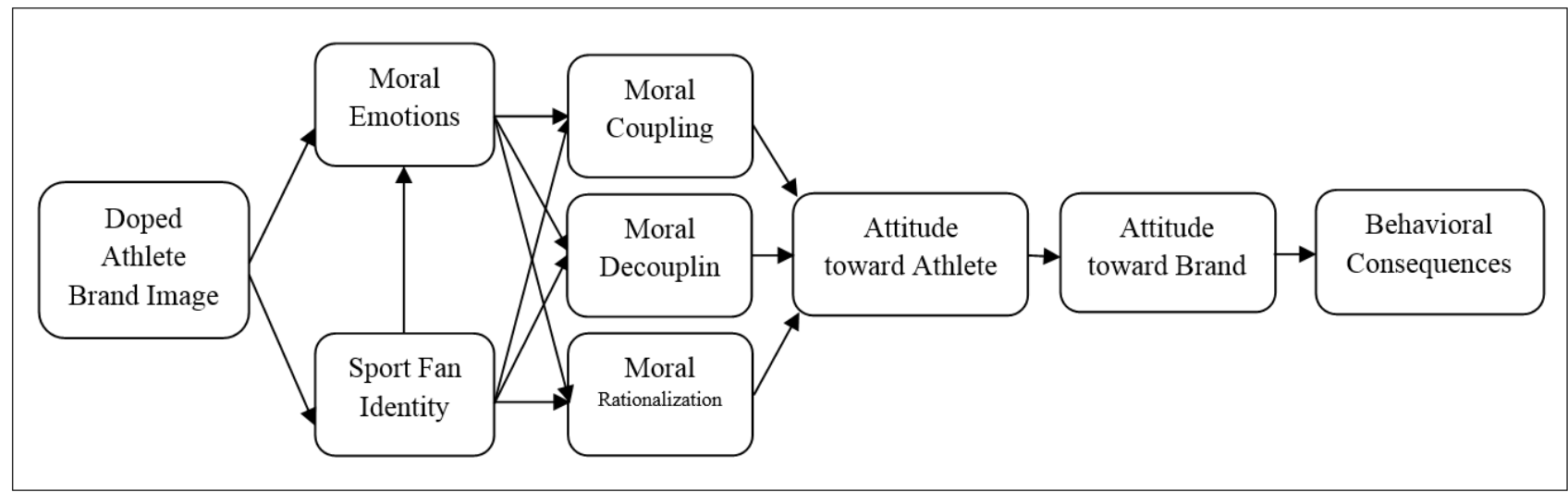

Figure 1. Model of Doping Phenomenon Effect on Sport Marketing in Iran

\section{Discussion and Conclusion}

The main aim of the present research was to explore the effect of celebrities' doping scandal on sport marketing which were investigated in two fields of brand and consumer behavioral consequences. Despite the marital corruption, Tiger Woods affected purchase intention of Nike consumer significantly. Data analysis showed that purchase intention was increasing when Woods endorsed the Nike. The effects on brand image were in contrary to purchase intention. Therefore, organizations can keep utilizing athlete endorser committed to misbehavior although worth decreases for brand image because consumers adjust negative information around athlete when they make purchase decision (Lohneiss \& Hill, 2014). On the other side, present results rejected any transgression and doping violation. Other researchers acknowledged that consumers do not endure doping substances. A large number of them interested in unfavorable reaction to doped athletes (Solberg, Hanstad, \& Thöring, 2010; Stamm, Lamprecht, Kamber, Marti, \& Mahler, 2008; Moston, Skinner, \& Engelberg, 2012; Reeth \& Lagae, 2013). This clarification about athlete brand image and endorsed product brand image is consistent with the present results. In addition, other findings showed that negative publicity impacts of negative event relating to the endorsed resource resulted in transferring image and affecting consumers' attitude toward sponsor company negatively (Runsbech \& Sjolin, 2011; Carstairs, 2003; Matos \& Veiga, 2005; Thwaites, Lowe, Monkhouse, \& Barnes, 2012; Wilson, Stavros, \& Westberg, 2008). Likewise, some of them found that using athlete celebrity is highly effective if both celebrity and endorsed brand have conformity with each other (Charbonneau \& Garland, 2005; Kim \& Na, 2007; Chernev, Hamilton, \& Gal, 2011). On the 


\section{Designing a Qualitative Model of Doping Phenomenon Effect on Sport Marketing in}

Iran

other hand, previous results showed that personal value of celebrity endorsers may be decreased when they involve in doping scandal, and the same image is conceptualized by consumer for the endorsed product. Moreover, image transfer is known as a predictor for purchase intentions respecting to event sponsor product (Tan \& Burman, 2013; Mazanov \& Connor, 2010; Gwinner, 1997; Gwinner, Larson, \& Swanson, 2009; Hughes \& Shank, 2005; Roozen, 2012). It seems that, as already demonstrated in the proposed research model and supporting previous findings, athlete image who convicted to doping scandal was negative to consumers and this negative image might be transferred to the endorsed product brand. This negative image may have unfavorable consequences for the product in a way that consumer's related emotions were destroyed. In that case, literature review suggested that it stimulates consumer to have negative moral emotions, negative word of mouth and protests against company (Grappi, Romani, \& Bagozzi, 2013; Thomson, 2006; Belesioti, 2011; Kwak, Kim, \& Zimmerman, 2010). Additionally, negative celebrities' publicities lead to weakening companies brands (Johnson, 2005; Doss, 2011). However, mentioned points might be adjusted by some variables. For instance, data analysis revealed that consumer identity with athlete and product may decrease consumer negative behavioral consequences. For instance, previous results indicated that there is strong relationship between identity power and emerging supportive behaviors (Fisher \& Wakefield, 1998; Gwinner, \& Swanson, 2003; Um, 2013; Stokburger-Sauer, Ratneshwar, \& Sen, 2012; Katoch, 2009; Parker \& Fink, 2010). In addition to identity, moral reasoning strategies of cognitive dissonance may cope with conflicting attitudes of consumer. The present results made it clear that moral reasoning leads persons who are dissident with doping tend to support the doped athlete and purchase the endorsed product again. Research literature also supports the existence of moral reasoning of conflicting attitudes or cognitive dissonance. Previous results showed that, in case of public image transgressions, moral decoupling can predict support or withdraw by consumer more than moral rationalization (Bhattacharjee, Berman, \& Reed, 2013). Moreover, moral coupling is common and has a unique predictive role to describe evaluating violation by consumer. The results also showed that unethical behavior of public images and spreading to a wider brand depends on moral reasoning choices of consumers (Lee \& Kwak, 2015).

Finally and respecting to the documented cases in the competitive modern sport industry and regarding merchandises and services consumers interests in fair and clean sport and their orientation to positive brands in marketplace which are affected by endorsement activities, it is evident that producer companies that advertised by celebrities must care about probable misbehaviors and potential consequences. Since doping violation in sport leads to decreasing in number of spectators in sport events (Cisyk \& Courty, 2015; Bednall \& Collings, 2000; Ahluwalia, Burnkrant, \& Unnava, 2000).

The present research was limited to qualitative interviews; therefore, it is proposed that related studies should be of interesting for future scholars by using a widespread society with a quantitative approach in order to generalize collected data. In addition, it seems that endorsed brand and product owners are the main group affecting by negative consequences and their main concern is to repair brand image to consumers after endorsers' scandals. Accordingly, investigating repairing strategies for brand image and attitude toward an advertised brand endorsing by a doped celebrity should be considered by future studies. 


\section{REFERENCES}

Aaker, J.L. (1997). Dimensions of brand personality. Journal of Marketing Research, 34(3), 347-356.

Aaker, D.A. (2008). Strategic market management. New Jersey, John Wiley \& Sons, Inc.

Ahluwalia, R., Burnkrant, R. E., \& Unnava, H. R. (2000). Consumer response to negative publicity: The moderating role of commitment. Journal of Marketing Research, 37(2), 203-214.

Bazargan, A. (2012). Introduction to qualitative and mixed research methods: common approach in behavioral sciences. Tehran, Didar publication, third edition.

Buechel, B., Emrich, E., \& Pohlkamp, S. (2014). Nobody's Innocent: The Role of Customers in the Doping Dilemma. Journal of Sport Economics, doi: $10.1177 / 1527002514551475$.

Bandura, A. (1991). Social Cognitive Theory of Moral Thought and Action. In W. M. Kurtines \& J. L. Gewirtz (Eds.), Handbook of moral behavior and development: Theory, research, and applications (Vol. 1), Hillsdale, NJ: Erlbaum.

Bednall, D. H., \& Collings, A. (2000). Effect of public disgrace on celebrity endorser value. Australasian Marketing Journal, 8(2), 47-57.

Belesioti, O. (2011). Can negative publicity of celebrities' endorsement damage the reputation of a brand? University of Amsterdam Faculty of Economics and Business Department, Marketing and Strategy Master Thesis MSc.
Bhattacharjee, A., Berman, J. Z., \& Reed, A. (2013). Tip of the hat, wag of the finger: How moral decoupling enables consumers to admire and admonish. Journal of Consumer Research, 39(6), 1167-1184.

Blackwell, R. D., Miniard, P. W., \& Engel, J. F. (2001). Consumer Behavior. Harcourt College Publishers, $9^{\text {th }}$ edition.

Carstairs, C. (2003). The wide world of doping: drug scandals, natural bodies and the business of sports entertainment. Addiction Research and Theory, 11(4), 263281.

Charbonneau, J., \& Garland, R. (2005). Talent, looks or brains? New Zealand advertising practitioners' views on celebrity and athlete endorsers. Marketing Bulletin, 16(3), 1-10.

Chernev, A., Hamilton, R., \& Gal, D. (2011). Competing for consumer identity: Limits to self-expression and the perils of lifestyle branding. Journal of Marketing, 75(3), 66-82.

Cisyk, J., \& Courty, P. (2015). Do fans care about compliance to doping regulations in sports? The impact of PED suspension in Baseball. Journal of Sports Economics, 1, 1-26.

Danaeifard, H., Alvani, S.M., and Azar, A. (2013). Qualitative research methodology in management: a comprehensive approach. Tehran, Eshraghi Safaar publication, 2nd edition.

Dilger, A., Frick, B., \& Tolsdorf, F. (2007), Are Athletes Doped? Some Theoretical Arguments and Empirical 


\section{Designing a Qualitative Model of Doping Phenomenon Effect on Sport Marketing in}

Evidence. Contemporary Economic Policy, 25, 604-615.

Doss, S. (2011). The transference of brand attitude: the effect on the celebrity endorser. Journal of Management and Marketing Research, 7, 1-11.

Fazen, G. (1999). Brand and advertising: How advertising effectiveness influences brand equity. Oxford Shire, United Kingdom: Admap Publication.

Festinger, L. (1957). A theory of cognitive dissonance. Stanford, CA: Stanford University Press.

Fisher, R.J., \& Wakefield, K. (1998). Factors leading to group identification: A field study of winners and losers. Psychology \& Marketing, 15(1), 23-40.

Florez, C.L. (2013). The impact of the doping effect on cycling sponsorship: analysis of brand lovers and cycling fans consumer reaction. Kassel, Germany, Master Thesis in Business Studies.

Funk, D.C. (2011). Consumer Behaviour in Sport and Events - Marketing Action. Taylor \& Francis.

Grappi, S., Romani, S., \& Bagozzi, R. P. (2013) Consumer response to corporate irresponsible behavior: Moral emotions and virtues. Journal of Business Research, 66(10), 1814-1821.

Gwinner, K. (1997). A model of image creation and image transfer in event sponsorship. International Marketing Review, 14(3), 145-158.

Gwinner, K.P., Larson, B.V., \& Swanson, S.R. (2009). Image Transfer in Corporate Event Sponsorship: Assessing the Impact of Team Identification and Event-Sponsor Fit. International Journal of
Management and Marketing Research, 2(1): 1-15.

Gwinner, K., \& Swanson, S. R. (2003). A model of fan identification: Antecedents and sponsorship outcomes. The Journal of Service Marketing, 17(3), 275-294.

Haidt, J. (2001). The emotional dog and its rational tail: A social intuitionist approach to moral judgment. Psychological Review, 108(4), 814-834.

Haidt, J. (2007). The new synthesis in moral psychology. Science, 316(5827), 998-1002.

Hoberman, J.M. (1992). Mortal Engines: The Science of Performance and the Dehumanization of Sport. New York: Free Press.

Houlihan, B. (2002). Dying to Win: Doping in Sport and the Development of Anti-doping Policy. Strasbourg: Council of Europe Publishing.

Hughes, S., \& Shank, M. (2005). Defining scandal in sports: Media and corporate sponsor perspectives. Sport Marketing Quarterly, 14(4), 207-216.

Johnson, A.R. (2005). When a celebrity is tied to immoral behavior: Consumer reactions to Michael Jackson and Kobe Bryant. Advances in Consumer Research, 32, 100-101.

Katoch, A. (2009). The application of social identity theory and theory of planned behavior on the role of sports brand sponsorship (Unpublished master's thesis). National Cheng Kung University, Institute of International Management.

Kim, Y., \& Na, J. (2007). Effects of celebrity athlete endorsement on attitude towards the product: the role of credibility, 


\section{Designing a Qualitative Model of Doping Phenomenon Effect on Sport Marketing in}

attractiveness and the concept of congruence. International Journal of Sports Marketing and Sponsorship, 8(4), 310-320.

Kwak, D.H., Kim, Y.K., \& Zimmerman, M.H. (2010). User-versus mainstream-media-generated content: Media source, message valence, and team identification and sport consumers' response. International Journal of Sport Communication, 3(4), 402-421.

Lee, J.S. (2015). Athlete Endorser's Transgression and Sport Consumer's Moral Reasoning Strategy: Moral Coupling and Boundary Conditions (PhD Dissertation). University of Michigan, pages 1-7.

Lee, J.S., \& Kwak, D.H. (2015). Consumers' responses to public figures' transgression: Moral reasoning strategies and implications for endorsed brands. Journal of Business Ethics, DOI 10.1007/s10551-015-2544-1.

Lohneiss, A., \& Hill, B. (2014). The impact of processing athlete transgressions on brand image and purchase intent. European Sport Management Quarterly, 14(2), 171-193.

Litvin, S.W., Goldsmith, R.E., \& Pan, B. (2008). Electronic word of mouth in hospitality and tourism management. Tourism management, 29(3), 458-468.

Matos, C.A., and Veiga, R.T. (2005). How to Deal with Negative Publicity: the Importance of Consumer Involvement. Brazilian Administration Review, 2 (1), 5772.

Mazanov, J., \& Connor, J. (2010). The role of scandal and corruption in sports marketing and sponsorship. International Journal of Sports Marketing \& Sponsorship, 11(3), 183.
McCracken, G. (1986). Culture and Consumption: A Theoretical Account of the Structure and Movement of the Cultural Meaning of Consumer Goods. Journal of Consumer Research, 13(1), 71-84.

Miles, M.B. \& Huberman, A.M. (1994). Qualitative data analysis: a source book of new methods. London, Sage, $2^{\text {nd }}$ edition.

Moston, S., Skinner, J. \& Engelberg, T. (2012). Perceived incidence of drug use in Australian sport: a survey of public opinion. Sport in Society, 15(1), 64-77.

Parker, H.M., \& Fink, J.S. (2010). Negative sponsor behavior, team response and how this impacts fan attitudes. International Journal of Sports Marketing \& Sponsorship, 11(3), 200-211.

Perron, L. (2009, June 6). Should NFL give Vick a second chance? Reuter. Retrieved from http://blogs.reuters.com/sport/2009/06/06/s hould-nfl-give-vick-a-secondchance/?cp=all\#comments

Prinz, J. (2006). The Emotional Basis of Moral Judgments. Philosophical Explorations, 9(1), 29-43.

Reeth, D.V., \& Lagae, W. (2013). Public opinion on doping in cycling: differences among population groups. Faculteit Economie En Bedrijfswetenschappen Campus Brussel (Hubrussel).

Research Rundowns (2016). Qualitative Coding \& Analysis. Retrieved from https://researchrundowns.com/qual/qualitat ive-coding-analysis/ 


\section{Designing a Qualitative Model of Doping Phenomenon Effect on Sport Marketing in}

Roosta, A., Venous, D., and Ebrahimi, A. (2013). Marketing Management. Tehran, Samt publication, $7^{\text {th }}$ edition.

Roozen, I. (2012). Negative publicity on the endorsement process does it influence for-profit and not for-profit print advertisements? Hub Research Papers Economics \& Management, 1, 1-16.

Rozin, P., Lowery, L., Imada, S., \& Haidt, J. (1999). The CAD triad hypothesis: A mapping between three moral emotions (contempt, anger, disgust) and three moral codes (community, autonomy, divinity). Journal of Personality and Social Psychology, 76(4), 574-586.

Runsbech, A., \& Sjolin, D. (2011). Negative effects of sponsorships a quantitative study on negative effects of image transfers through sponsorship in the U.K (Undergraduate thesis at C-level). Halmstad University, $15 \mathrm{Hp}$.

Simmers, C., Damron-Martinez, D., \& Haytko, D. (2009). Examining the Effectiveness of Athlete Celebrity Endorser Characteristics and Product Brand Type: The Endorser Expertise Continuum. Journal of Sport Administration \& Supervision, 1(1), 52-64.

Slack, T. (2004). Sport Comercialization. Translated by Razavi, M.H. \& Nobakhti, S. Mazandaran, Shomal Paydar publication.

Smith, A. (2008). Introduction to Sport Marketing. Elsevier ButterworthHeinemann, Business \& Economics.

Solberg, H.A., Hanstad, D.V., \& Thöring, T.A. (2010). Doping in elite sport, do the fans care? Public opinion on the consequences of doping scandals. International Journal of Sports Marketing \& Sponsorship, 11(3), 185-199.
Stamm, H., Lamprecht, M., Kamber, M., Marti, B. \& Mahler, N. (2008). The public perception of doping in sport in Switzerland, 1995-2004. Journal of Sports Sciences, 26(3), 235-242.

Stokburger-Sauer, N., Ratneshwar, S., \& Sen, S. (2012). Drivers of consumerbrand identification. International Journal of Research in Marketing, 29(4), 406-418.

Tan, L., \& Burman, J. (2013). Effects of Doping Behaviour on Brand Image in Australian Sport. ANZMAC Conference, Department of Marketing \& Management, Macquarie University, Sydney Australia.

Tangney, J.P., Stuewig, J., \& Mashek, D.J. (2007). Moral emotions and moral behavior. Annual Review of Psychology, 58, 345-372.

Thomson, M. (2006). Human brands: Investigating antecedents to consumers' strong attachments to celebrities. Journal of Marketing, 70(3), 104-119.

Thwaites, D., Lowe, B., Monkhouse, L.L., \& Barnes, B.R. (2012). The impact of negative publicity on celebrity ad endorsements. Psychology \& Marketing, 29(9), 663-673.

Till, B.D., \& Shimp, T.A. (1998). Endorsers in advertising: The case of negative celebrity information. Journal of Advertising, 27(1), 67-82.

Um, N. (2013). Celebrity scandal fallout: How attribution style can protect the sponsor. Psychology \& Marketing, 30(6), 529-541.

Westbrook, R.A. (1987). Product/consumption-based affective responses and post purchase processes. Journal of Marketing Research, 24, 258270. 
Wilkie, W. (1986). Consumer behavior. New York: John Wiley - Wiley and Son, Inc.

Wilson, B., Stavros, C., \& Westberg, K. (2008). Player transgressions and the management of the sport sponsor relationship. Public Relations Review, 34(2), 99-107. 